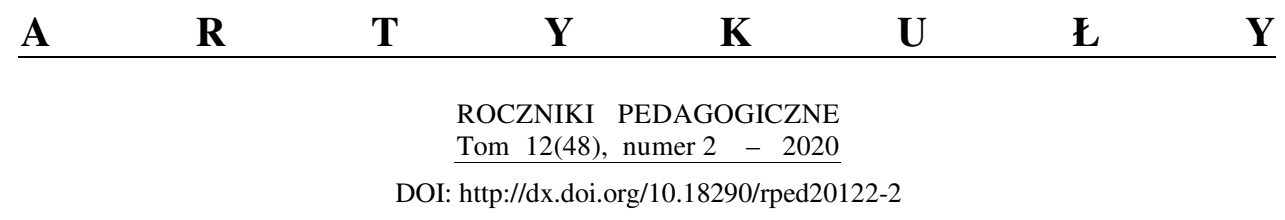

KS. ADAM MAJ

\title{
INNOWACJE I EKSPERYMENTY EDUKACYJNE - PODSTAWY PEDAGOGICZNE, PRAWNE I METODOLOGICZNE
}

Innowacyjność jest aktualnie postrzegana jako szczególnie pożądana postawa w działalności społecznej i gospodarczej, traktowana jako instrument postępu i rozwoju w krajach Unii Europejskiej, w tym Polski, i jej programów społeczno-gospodarczych. Z tego względu i z indywidualnych racji (wysoka jakość rozwoju własnej osobowości) stanowi pożądaną cechę współczesnego człowieka.

$\mathrm{W}$ tej perspektywie innowacyjność jawi się jako oczekiwany rys sytemu edukacji narodowej, reformowanej szkoły, szczególnie aktywności pedagogicznej i organizacyjnej nauczycieli. Co więcej, aktualne prawo oświatowe zobowiązuje do uwzględnienia innowacyjności w programie edukacyjnym każdej szkoły, w kształceniu i wychowania uczniów na wszystkich szczeblach oświaty.

Znaczenie i aktualność problematyki, wzmocnione wymaganiami prawa oświatowego, skłaniają do podjęcia przedmiotu poniższej analizy, którym jest innowacja edukacyjna (tu rozumiana jako pedagogiczna) i jej specyficzna forma - eksperyment pedagogiczny. Prezentowany aspekt pedagogiczny, prawny i metodologiczny stanowi podstawowy zarys podjętej problematyki, posiadającej bogatą tradycję teoretyczno-praktyczną w polskiej historii oświaty. W niektórych częściach podjętej tematyki wykorzystano własne opracowanie autora (Maj, 2016).

Ks. dr hab. AdAm MAj, prof. KUL - Katedra Dydaktyki i Edukacji Szkolnej, Instytut Pedagogiki Katolickiego Uniwersytetu Lubelskiego Jana Pawła II, Lublin; e-mail: adammaj@kul.pl; ORCID: https://orcid.org/0000-0002-0240-8013. 


\section{ASPEKT PEDAGOGICZNY}

Pedagogiczna analiza innowacyjności i eksperymentu wymaga ustalenia treści terminologicznej tych pojęć oraz ich pedagogicznej specyfiki.

Innowacyjność (łac. odnowienie) ogólnie oznacza „nowość, wprowadzenie czegoś nowego lub czegoś ulepszonego w jakimś obszarze" (Duraj, Papiernik-Wojdera, 2010, s. 61). Prekursorem i twórcą współczesnego znaczenia innowacyjności, zwłaszcza w naukach ekonomicznych, jest J.A. Schumpeter (1960). A. Biela charakteryzuje pojęcie innowacyjności jako zmianę aktualnego stanu systemu (układu, sytuacji) dokonującą się poprzez „włączenie nowych elementów bądź przez konstruowanie lub odkrywanie nowych relacji między elementami już istniejącymi” (Biela, 1997, f. 257), która prowadzi do nowej organizacji systemu lub odmiennego sposobu rozumienia sytuacji. Za A. Bielą można wyróżnić następujące elementy strukturalne innowacyjności:

- nowość (zmiana) - nowe elementy konstruowane, odkrywane lub stanowiące ulepszenie, udoskonalenie;

- implementacja - włączanie nowości do aktualnego systemu, sytuacji;

- nowa organizacja systemu lub odmienny sposób rozumienia sytuacji zmiana praktyczna $\mathrm{i}$ interpretacyjna $\mathrm{w}$ zakresie myślenia, koncepcji, realizacji (Biela, tamże).

Innowacyjność nie zakłada jakiejkolwiek zmiany, nie koncentruje się na sobie, ale implikuje zmianę twórczą, stanowiącą czynnik rozwoju i doskonalenia funkcjonowania określonego systemu (Popek, 1998, s. 919; Drucker, 1992, s. 44; Okoń, 2004, s. 430-431). W aspekcie osobowym innowacyjność należy rozumieć jako twórczą zmianę w zakresie myślenia i działania ludzkiego. Twórczość dookreśla zmiany innowacyjne jako cenne dla osobowości człowieka, jego rozwoju, realizacji potencjału ludzkiego, a także dla społeczeństwa, kultury czy gospodarki. W takim ujęciu innowacyjność jest dobrem moralnym, bo trzeba podkreślić, że nie każda innowacja jest moralnie uzasadniona, np. kreowanie sztucznych potrzeb konsumpcyjnych, złe cele zmian, naruszanie podmiotowości człowieka, pogarszanie warunków życia, nauki, pracy, środowiska (Biela, 1998, f. 258).

$\mathrm{Na}$ podstawie powyższej analizy istoty i cech innowacyjności można ustalić pojęcie innowacji pedagogicznej, którą rozumiemy jako nowość, zmianę w systemie edukacji jako całości lub struktury ważnych jego składników - w celu wprowadzenia ulepszeń (Okoń, 2004, s. 146), polegającą na tworzeniu i wdrażaniu nowych rozwiązań edukacyjnych, dotyczących celów, 
norm prawno-organizacyjnych, warunków, struktur, procesów lub mechanizmów kształcenia i wychowania (Milerski, Śliwerski, 2000, s. 85).

Innowacje pedagogiczne można w różny sposób kategoryzować. Ze względów pragmatycznych, istotnych w praktyce edukacyjnej szkoły, istotne znaczenie posiada podział kategorii innowacji pedagogicznych według kryterium oryginalności, kryterium formalnego oraz merytorycznego (zakresu przedmiotowego).

W pierwszym ujęciu innowacja pedagogiczna, jak każda inna, może być oryginalna - tworzenie i realizacja zupełnie nowego projektu zmian, oraz naśladowcza - wdrażanie sprawdzonych już nowości, ale oryginalnych dla danego systemu (Schulz, 1996).

W drugim ujęciu, za ministerialnym rozporządzeniem z 9 kwietnia 2002 r., wyróżnia się takie kategorie innowacji pedagogicznych, czyli nowatorskich rozwiązań mających na celu poprawę jakości pracy szkoły, jak:

- programowe,

- metodyczne,

- organizacyjne (Ministerstwo Edukacji Narodowej i Sportu, 2002).

Po trzecie, biorąc pod uwagę podstawowe obszary działalności szkoły: edukacyjny (dydaktyka i wychowanie; Milerski, Śliwerski, 2000, s. 54) oraz organizacyjny, można zaproponować kategoryzację merytoryczną, zawierającą następujące grupy kategorii innowacji pedagogicznych:

- dydaktyczne (programowe, metodyczne) - usprawniają proces nauczania-uczenia się, np. dotyczą modyfikacji programu, celów, treści, metod, środków, form kształcenia czy sposobów oceniania uczniów;

- wychowawcze (opiekuńcze, profilaktyczne, aksjologiczne, kulturowe, społeczne - środowiskowe) - doskonalą proces wychowawczy w zakresie celów, treści, zasad, metod, środków oraz form wychowania w klasie i w szkole, jego aksjologii, uwarunkowań (opieka, profilaktyka, klimat wychowawczy), form aktywności uczniów: artystycznej (kulturowej), społecznej (np. wolontariat);

- organizacyjne - dotyczą organizacji procesu edukacji i organizacji życia szkoły (np. liczebność klasy, czas trwania lekcji, dodatkowe godziny lekcyjne, zajęcia pozalekcyjne, współpraca ze środowiskiem oraz zarządzanie).

Każda innowacja jest zmianą, lecz nie każda zmiana jest innowacją. Innowacja pedagogiczna uwarunkowana jest stanem prawnym, organizacyjnym, dydaktyczno-wychowawczym oraz personalnym (potencjał pedagogiczny nauczycieli) konkretnej placówki oświatowej - dlatego to samo działanie 
w jednej szkole będzie innowacją, w innej nie uzyska takiego statusu. Trzeba też podkreślić konieczność określenia oczekiwanych celów, efektów innowacji pedagogicznej. Zdaniem K. Najder-Stefaniak innowacyjność pedagogiczna jest aktywnością: „celową - ukierunkowaną na określone efekty, jakie można dzięki niej uzyskać; planową - porządkowaną przez przemyślany harmonogram działań i czynności; organizowaną - przewiduje potrzebne zasoby, ludzi i środki; kontrolowaną - możemy śledzić przebieg aktywności innowacyjnej odnosząc ją do określonego sposobu ewaluacji”" (Najder-Stefaniak, 2010, s. 12).

Ponadto należy zaznaczyć, że innowacja pedagogiczna wiąże się z takimi kategoriami (wartościami), jak:

- twórczość - szkoła twórcza to szkoła innowacyjna, m.in. twórczy program, twórczy nauczyciel, aktywny uczeń, autorska klasa,

- kreatywność - myślenie kreatywne, prowadzące do uzyskania oryginalnych i stosownych rozwiązań (eksponowana w ustawie oświatowej i podstawie programowej),

- jakość - stałe doskonalenie osobowe i zespołowe (poszerzanie kompetencji), doskonalenie aktywności we wszystkich wymiarach edukacyjnych (Brzezińska, 1992, s. 69, 72-75; Szmidt, 2013, s. 84-90).

Specyficzną innowacją pedagogiczną jest eksperyment pedagogiczny, który polega na zastosowaniu w procesie edukacyjnym nowego czynnika (dydaktycznego, wychowawczego) i badaniu (obserwacji) dokonujących się zmian pod jego wpływem oraz ich waloryzacji w stosunku do zamierzonych efektów (Pilch, 1998, s. 43-45).

Eksperyment pedagogiczny wymaga precyzyjnego określenia czynnika zmian, zamierzonego efektu jako celu eksperymentu, metody badań (obserwacji, kryteriów oceny), zasad moralnych (nienarażanie uczniów na jakiekolwiek straty).

Innowacja pedagogiczna ma wiele walorów, ponieważ:

- jest czynnikiem rozwoju szkoły i jej kultury,

- wzbogaca i uatrakcyjnia proces kształcenia i wychowania, podnosi jego efektywność,

- dynamizuje integralny rozwój osobowy uczniów,

- przyczynia się do podniesienia kompetencji pedagogicznych nauczycieli oraz ich rozwoju osobowego,

- może aktywizować szkołę (klasę szkolną) w służbie na rzecz środowiska lokalnego, 
- w przypadku eksperymentu pedagogicznego pogłębia kompetencje teoretyczne (naukowe) nauczycieli.

\section{ASPEKT PRAWNY}

Istotnym dla praktyki edukacyjnej jest aspekt normatywny, stanowiony przez prawo oświatowe i obligatoryjny dla polskiej szkoły. Przez prawie dwie dekady, od 2002 r. obowiązywało wspomniane wyżej rozporządzenie ministra edukacji narodowej i sportu z dnia 9 kwietnia 2002 r. w sprawie warunków prowadzenia działalności innowacyjnej i eksperymentalnej przez publiczne szkoły i placówki (Dz.U. z 2002 r. Nr 56, poz. 506 z póź. zm.). Natomiast obecnie, od 1 września 2017 r., powyższe rozporządzenie straciło prawomocność, a regulacje prawne dotyczące działalności innowacyjnej szkoły przeniesiono na poziom adekwatnych ustaw, rezygnując z upoważnienia ministra edukacji do określenia w drodze rozporządzenia warunków prowadzenia innowacji przez szkoły.

Zgodnie ze strategią aktualnej reformy oświaty zmiany polegają na zniesieniu konieczności zgłaszania innowacji pedagogicznej kuratorowi oświaty i organowi prowadzącemu oraz zniesieniu wymagań formalnych, warunkujących rozpoczęcie innowacji.

Odtąd szkoła samodzielnie podejmuje decyzję w sprawie innowacji, procedur ich wdrażania i dokumentowania, ponieważ innowacyjność stanowi integralny element funkcjonowania szkoły. Zatem jest to istotna zmiana normatywna, inspirująca szkołę do twórczych działań pedagogicznych i organizacyjnych.

Podstawę prawną nowych rozwiązań w zakresie innowacyjności w polskiej szkole zawierają następujące ustawy:

- O systemie oświaty z 7 września 1991 r. (tekst jedn.: Dz.U. 2016, poz. $1943)$ - art. 41 ust. 1 pkt 3 , art. 50 ust. 2;

- Prawo oświatowe z 14 grudnia 2016 r. (Dz.U. 2017 r., poz. 59; tekst jednolity: Dz.U. 2018, poz. 996) - art. 1 pkt 18, art. 44 ust. 2 pkt 3, art. 55 ust. 1 pkt 4 , art. 68 ust. 1 pkt 9 , art. 86 ust. 1;

- Przepisy wprowadzające ustawę Prawo oświatowe z 14 grudnia 2016 r. (Dz.U. 2017, poz. 60) - art. 15 pkt 29b.

Ze względu na merytoryczny i teleologiczny charakter na uwagę zasługują normy prawne zawarte w ustawie Prawo oświatowe, które określają: 
- konieczność kształtowania u uczniów postaw przedsiębiorczości i kreatywności, „w tym poprzez stosowanie w procesie kształcenia innowacyjnych rozwiązań programowych, organizacyjnych lub metodycznych" (art. 1 pkt 18);

- obowiązek tworzenia przez szkoły i placówki „warunków do rozwoju aktywności, w tym kreatywności uczniów" (art. 44 ust. 2 pkt 3);

- możliwość wspierania nauczycieli, w ramach nadzoru pedagogicznego, w realizacji zadań służących poprawie „istniejących lub wdrożeniu nowych rozwiązań w procesie kształcenia, przy zastosowaniu nowatorskich działań programowych, organizacyjnych lub metodycznych" (art. 55 ust. 1 pkt 4).

- obowiązek stwarzania przez dyrektora warunków „,do działania w szkole wolontariuszy, stowarzyszeń i innych organizacji, w szczególności harcerstwa, których celem statutowym jest działalność wychowawcza lub wzbogacanie form działalności dydaktycznej, wychowawczej, opiekuńczej i innowacyjnej szkoły" (art. 68 ust. 1 pkt 9);

- warunki, na jakich w szkole „mogą działać, z wyjątkiem partii i organizacji politycznych, stowarzyszenia i inne organizacje, a w szczególności organizacje harcerskie, których celem statutowym jest działalność wychowawcza albo rozszerzanie i wzbogacanie form działalności dydaktycznej, wychowawczej, opiekuńczej i innowacyjnej szkoły" (art. 86 ust. 1).

Powyższe normy prawne podtrzymują podział innowacji szkolnych zawarty w rozporządzeniu ministerialnym z 2002 r. na innowacje programowe, metodyczne i organizacyjne, które nie są sprzeczne z proponowanym podziałem merytorycznym na dydaktyczne, wychowawcze i organizacyjne. Zarazem kierunkują działalność innowacyjną na wykształcenie i wychowanie u uczniów postaw kreatywnych, dopuszczając przy tym celowe działania stowarzyszeń i organizacji pozaszkolnych, zwłaszcza harcerstwa.

W zakresie eksperymentu pedagogicznego ustawa Prawo oświatowe ustala w art. 45 szczegółowe regulacje. Stwierdza się w nim, że szkoła „może realizować eksperyment pedagogiczny, który polega na modyfikacji istniejących lub wdrożeniu nowych działań w procesie kształcenia, przy zastosowaniu nowatorskich rozwiązań programowych, organizacyjnych, metodycznych lub wychowawczych, w ramach których są modyfikowane warunki, organizacja zajęć edukacyjnych lub zakres treści nauczania" (art. 45.1.).

Wskazuje się na cel eksperymentu, którym ,jest rozwijanie kompetencji i wiedzy uczniów oraz nauczycieli" (art. 45.2.) oraz określa się warunki realizacji eksperymentu, czyli:

- opieka odpowiedniej jednostki naukowej (art. 45.3.); 
- niemożność zmiany typu szkoły (art. 45.4.) i naruszenia „uprawnień ucznia do bezpłatnej nauki, wychowania i opieki, a także w zakresie uzyskania wiadomości i umiejętności niezbędnych do ukończenia danego typu szkoły oraz warunków i sposobu przeprowadzania egzaminów" (art. 45.5.);

- konieczność zachowania procedury prawnej: uchwała rady pedagogicznej i opinia rady rodziców, w przypadku dodatkowych kosztów zgoda organu prowadzącego (art. 45.12.), sformułowanie wniosku (do 31 marca roku szkolnego poprzedzającego rok szkolny, w którym jest planowane rozpoczęcie eksperymentu) za pośrednictwem kuratora oświaty do właściwego ministra i uzyskanie jego zgody (art. 45.8-11.), zobowiązanie do szczegółowej sprawozdawczości z przeprowadzonego eksperymentu (art. 45.13-15.).

Rekrutacja do szkoły, w której jest przeprowadzany eksperyment pedagogiczny, może dokonywać się na specyficznych zasadach, ale za zgodą odpowiedniego ministra (art. 45.6.). Zaznacza się, że „eksperyment pedagogiczny może obejmować całą szkołę, oddział, grupę lub wybrane zajęcia edukacyjne" (art. 45.7).

Podsumowując, można stwierdzić, że polskie prawo oświatowe nie tylko sprzyja innowacyjnej działalności szkół, lecz także ją obligatoryjnie wymusza. Aktualne prawo nie wprowadza zmian w kategoryzacji innowacji pedagogicznych przyjętej w ustawie z 2002 r. (programowe, metodyczne, organizacyjne), ale z kontekstu wynika, że innowacje typu wychowawczego są możliwe do realizacji, co explicite zawarto w przypadku eksperymentu pedagogicznego (art. 45.1.). Wspomniany eksperyment pedagogiczny jako specyficzna innowacja znajduje właściwe zapisy w ustawie Prawo oświatowe, uzasadnione potrzebą dogłębnego namysłu nad jego celem, realizacją i efektami, które nie mogą w żaden sposób stanowić jakiegokolwiek zagrożenia dla uczniów szkoły.

\section{ASPEKT METODOLOGICZNY}

Ustalenie innowacji edukacyjnej czy eksperymentu pedagogicznego oraz ich wdrażanie wymaga podjęcia szeregu czynności - m.in. teoretycznych, koncepcyjnych, badawczych, ewaluatywnych - na różnych etapach przygotowania, realizacji i ewaluacji.

Całokształt uzasadnionych teoretycznie i praktycznie sposobów formułowania innowacji lub eksperymentu pedagogicznego, wdrożenia ich w rzeczywistość szkolną oraz ich ewaluacji możemy określić metodologią, nawiązując do potocznego i naukowego rozumienia tego pojęcia. 
Można przyjąć cztery podstawowe etapy realizacji innowacji pedagogicznych w szkole, które obejmują szereg niezbędnych czynności, warunkujących ich adekwatność i efektywność (Maj, 2012, s. 24-29); są nimi:

- etap wstępny (diagnostyczny i selekcyjny),

- etap koncepcyjny,

- etap wdrożeniowy,

- etap ewaluatywny.

$\mathrm{Na}$ wstępnym etapie nauczyciele reformowanej szkoły (także przedszkola czy innej placówki oświatowej) powinni postawić sobie zasadnicze pytanie: jakie działania można lub należy podjąć, aby ulepszyć, usprawnić, udoskonalić działalność szkoły w zakresie organizacyjnym, dydaktycznym i wychowawczym, dla dobra uczniów i podwyższenia efektywności ich integralnego rozwoju?

Odpowiedź na powyższe pytanie wiąże się z koniecznością:

- diagnozy rzeczywistości szkolnej jako całości, konkretnej klasy czy grupy edukacyjnej w zakresie dydaktycznym i wychowawczym (w tym opiekuńczym i profilaktycznym) oraz organizacyjnym;

- rozpoznania faktycznych potrzeb osobowościowych i edukacyjnych uczniów;

- samooceny własnych kompetencji przez nauczycieli oraz waloryzacji własnych działań edukacyjnych i ich skuteczności (program nauczania, podręczniki, stosowane metody, formy i środki dydaktyczne, relacje z uczniami i ich rodzicami, sposób wychowania w klasie szkolnej, aksjologia wychowania i kształcenia, problemy wychowawcze itp.);

- poszukiwania wiedzy teoretycznej w zakresie rozumienia współczesnych procesów wychowawczych i dydaktycznych, orientacji w propozycjach innowacyjnych dostępnych w literaturze, w internecie $\mathrm{i} w$ ramach poznanych praktyk pedagogicznych innych szkół (dzielenie się doświadczeniami);

- zaangażowania się każdego nauczyciela w innowacyjność.

Ten etap domaga się umiejętności dokonania realnej oceny sytuacji w szkole, w klasie szkolnej i własnego warsztatu pedagogicznego nauczyciela oraz ustalenia listy proponowanych zmian innowacyjnych, adekwatnych do sytuacji uczniów, szkoły i możliwości nauczycieli, obejmujących całość działalności szkoły, czyli trzy jej obszary: dydaktyczny, wychowawczy i organizacyjny (trzy kategorie innowacyjności).

Drugi etap - koncepcyjny, polega na ustaleniu konkretnej innowacji w ramach selekcji proponowanych zmian innowacyjnych, które są niezbędne, pilne, możliwe do realizacji przez nauczyciela (czy zespół nauczycieli), w szczególności: 
- sformułowaniu tytułu innowacji,

- ustaleniu jej merytorycznej kategorii: dydaktyczna, wychowawcza, organizacyjna,

- określeniu formy innowacji - programowa, metodyczna, organizacyjna w ramach poszczególnych kategorii,

- opracowaniu programu realizacji innowacji.

Program jako uporządkowany scenariusz działalności innowacyjnej powinien zawierać: tytuł innowacji, jej kategoryzację merytoryczną i formalną, adresata (szkoła, klasa, grupa edukacyjna), okres wdrożeniowy, a także cel ogólny i cele szczegółowe (to, co chce się osiągnąć), zadania wynikające z celów szczegółowych, treści innowacji przypisane do zadań, metodykę realizacji zadań (metody, formy, środki, czyli procedury osiągania celu), przewidywane efekty, harmonogram realizacji zadań, ewaluację (zestaw narzędzi i kryteriów).

Fachowo opracowany program na około dwie strony (np. w wersji tabelarycznej w układzie poziomym) powinien zawierać krótką, elementarną bibliografię (nie tylko naukową, lecz także popularnonaukową, oświatową czy prawną), wskazującą na znajomość teoretyczno-praktyczną podejmowanej problematyki innowacyjnej.

Zwieńczeniem prac wstępnych i koncepcyjnych jest przedstawienie programu innowacyjnego przez nauczyciela (grupę nauczycieli) dyrektorowi szkoły i radzie pedagogicznej do akceptacji, zgodnie $\mathrm{z}$ obowiązującymi w szkole procedurami (określonymi w statucie).

Uzyskanie zgody uruchamia trzeci etap - wdrożeniowy, który implikuje zaangażowanie nauczyciela w realizację programu innowacji, nakłada na niego obowiązek bieżącego monitoringu (cząstkowej ewaluacji) i dokonywania ewentualnych korekt. Jest to etap przejścia od koncepcji (idei, programu) do realnego świata (urzeczywistnianie idei, koncepcji).

Etap ewolutywny jest dopełnieniem procesu tworzenia i realizacji innowacji pedagogicznej, zawierającym rzetelną ocenę wdrażanej innowacji, uwzględniającym mocne i słabe jej strony, kreującym na przyszłość doskonalącą strategię. W przypadku zdecydowanie pozytywnych ocen innowacja wdrażana w szkole powinna być utrwalona i implementowana do określonego obszaru jej działalności jako jej standardowy element.

Metodologia eksperymentu pedagogicznego, opracowanego i wdrażanego przez szkołę, jest wypadkową wyżej wspominanej procedury realizacji innowacji szkolnych, metody eksperymentu szkolnego opisanego w teorii badań pedagogicznych (m.in. przez D.T. Cambella i J.C. Stanleya, W. Zaczyńskiego, 
T. Pilcha, A. Janowskiego, M. Łobockiego) oraz wymagań określonych przez ustawę Prawo oświatowe (art. 45). Ze względu na swoją istotę eksperyment pedagogiczny wymaga odniesienia się do podstaw teoretycznych i nadzoru naukowego ośrodka akademickiego oraz wspólnego ze szkołą (nauczycielami, rodzicami i uczniami) namysłu i oceny etycznej treści, procedury i efektów eksperymentu. Ogniwami eksperymentu pedagogicznego są: formułowanie tematyki i problemu eksperymentu (czynnika stymulującego), hipoteza robocza i skutki, wybór metody, techniki, narzędzi realizacji i badań, ustalenie stanu wyjściowego i końcowego, weryfikacja hipotez, wnioski końcowe. Wyróżnia się kilka technik eksperymentu: grup równoległych (porównawczych), czterech grup, rotacji oraz technika jednej grupy, która polega na wprowadzeniu do danej sytuacji czynnika eksperymentalnego i badaniu zmian powstałych pod jego wpływem (Łobocki, 1999, s. 225-227).

Chociaż opracowanie i wdrażanie innowacji oraz eksperymentu pedagogicznego nie ma ściśle naukowego charakteru i jest przejawem badań oświatowych, to jednak wymaga od nauczycieli pogłębienia wiedzy teoretycznej w zakresie:

- procesu dydaktycznego i jego metodyki (metod, form, środków),

- procesu wychowania, roli aksjologii i metodyki wychowania (metod, form, środków),

- metodologii badań pedagogicznych (w zakresie formułowania celów, przedmiotu, problemów, hipotez badawczych, metod, technik i narzędzi badawczych),

- zasad konstruowania programów edukacyjnych.

\section{ZAKOŃCZENIE}

Zmiany w prawie oświatowym zobowiązują każdą szkołę do realizacji innowacji programowych, metodycznych i organizacyjnych w działalności dydaktycznej, wychowawczej i administracyjno-organizacyjnej. Innowacyjność staje się zwyczajnym przedmiotem pracy szkoły i jej nauczycieli. Jako twórcza nowość stanowi czynnik doskonalenia pracy szkoły i jej rozwoju. Chociaż aktywność innowacyjna jest na miarę kompetencji każdego nauczyciela, to jednak wymaga od niego pogłębiania wiedzy pedagogicznej i prawnej, zaangażowania się w wychowywanie uczniów do innowacyjności, która jest wartością inspirującą ich rozwój i przygotowującą do życia we współczesnym społeczeństwie. Trzeba podkreślić, że innowacyjność zmienia szkołę 
w twórcze środowisko edukacyjne, bardziej przyjazne i skuteczne w misji kształcenia i wychowania uczniów, rozwoju ich człowieczeństwa. Miłość wychowawcza do młodego pokolenia pozostaje ostatecznym i najwyższym motywem innowacyjnej aktywności nauczycieli i szkoły.

\section{BIBLIOGRAFIA}

BIELA, A. (1997). Innowacja. W: Encyklopedia katolicka. T. 7. Lublin: Wydawnictwo KUL.

BRZEZIŃSKA, A. (1992). Szkoła twórcza - autorskie klasy, programy, nauczyciel. Kwartalnik Pedagogiczny, 37(2), 69-75.

DruCKer, P.F. (1992). Innowacja i przedsiębiorczość. Praktyka i zasady. Warszawa: Państwowe Wydawnictwo Ekonomiczne.

DuRAJ, J., PAPIERnIK-WoJdera, M. (2010). Przedsiębiorczość i innowacyjność. Warszawa: Difin.

Łовоскі, М. (1999). Wprowadzenie do metodologii badań pedagogicznych. Kraków: Impuls.

MAJ, A. (2012). Pedagogiczne aspekty zarządzania rozwojem szkoły. W: A. MAJ, E. DomagaŁA-ZYŚK (red.). Zarzadzanie szkoła w procesie zmian oświatowych. Lublin: Wydawnictwo KUL.

MaJ, A. (2016). Wychowanie do innowacyjności i przedsiębiorczości. W: K. CHAŁAS, A. MAJ (red.). Encyklopedia aksjologii pedagogicznej. Radom: POLWEN.

Milerski, B., Śliwerski, B. (2000). Pedagogika. Leksykon PWN. Warszawa: Wydawnictwo Naukowe PWN.

Ministerstwo EdUKACJI NAROdOWEJ I SPORTU (9 IV 2002). Rozporzadzenie w sprawie warunków prowadzenia działalności innowacyjnej i eksperymentalnej przez publiczne szkoły i placówki.

NAJDER-STEFANIAK, K. (2010). Wstęp do innowatyki. Warszawa: Wydawnictwo SGGW.

ОкоŃ, W. (2004). Nowy stownik pedagogiczny. Warszawa: Wydawnictwo Akademickie „Żak”.

PILCH, T. (1998). Zasady badań pedagogicznych. Warszawa: Wydawnictwo Akademickie „Żak”.

PoPeK, S. (1998). Twórczość. W: W. SzEwCZuK (red.). Encyklopedia psychologii. Warszawa: Fundacja Innowacja.

Rowid, H. (1958). Szkoła twórcza. Warszawa: Wydawnictwa Szkolne i Pedagogiczne.

Schulz, R. (1996). Studia z innowatyki pedagogicznej. Toruń: Edytor.

SCHumpeter, J.A. (1960). Teoria rozwoju gospodarczego. Warszawa: Państwowe Wydawnictwo Naukowe.

SzmidT, K.J. (2013). Pedagogika twórczości. Sopot: Gdańskie Wydawnictwo Psychologiczne.

Ustawa z 14 grudnia 2016 r. Prawo oświatowe (Dz.U. 2017 r., poz. 59; tekst jednolity: Dz.U. 2018, poz. 996).

Ustawa z 14 grudnia 2016 r. Przepisy wprowadzające ustawę Prawo oświatowe (Dz.U. 2017, poz. 60).

Ustawa z 7 września 1991 r. o systemie oświaty (tekst jednolity: Dz.U. 2016, poz. 1943). 


\section{INNOWACJE I EKSPERYMENTY EDUKACYJNE - PODSTAWY PEDAGOGICZNE, PRAWNE I METODOLOGICZNE}

\section{STRESZCZENIE}

Innowacja pedagogiczna jest twórczą zmianą w działalności dydaktycznej i wychowawczej szkoły. Dotyczy programu, metodyki i organizacji pracy szkoły. Zgodnie z normami aktualnej reformy oświaty innowacyjność pedagogiczna jest obowiązkiem każdej szkoły, która powinna kształtować u uczniów postawę innowacyjną, przedsiębiorczą i kreatywną. Metodologia opracowania innowacyjności pedagogicznej wymaga od nauczycieli twórczych kompetencji i zaangażowania. W przypadku eksperymentu pedagogicznego dodatkowo wymagana jest współpraca z naukowcami i zezwolenie ministerstwa. Innowacyjność jest czynnikiem rozwoju szkoły i skutecznej służby młodemu pokoleniu.

Słowa kluczowe: innowacja; eksperyment; edukacja.

\section{INNOVATION AND EDUCATIONAL EXPERIMENTS - PEDAGOGICAL, LEGAL AND METHODOLOGICAL BASIS}

\section{SUMMARY}

Pedagogical innovation is a creative change in the didactic and educational activity of the school. Applies to the school's program, methodology and organization. According to the standards of the current education reform, pedagogical innovation is the responsibility of every school, which should shape students' innovative, entrepreneurial and creative attitude. The methodology for pedagogical innovation requires creative competence and commitment from teachers. In the case of a pedagogical experiment, cooperation with scientists and the permission of the ministry are additionally required. Innovation is a factor in the development of the school and effective service to the young generation.

Key words: innovation; experiment; education. 